\title{
SOME NEW PALAEARCTIC FLEAS.
}

BY DR. KARL JORDAN.

(With text-figures 9 to 18. .)

1. Ctenophthalmus jeanneli sp. nov. (text-figs. 9 ô, 10 ㅇ).

THE discovery of a Spalax flea in Transsylvania different from the Spalax flea known from the Deliblat and Croatia is surprising.

$\widehat{\jmath}$ ㅇ․ Proboscis reaching to or a little beyond apex of forecoxa. Bristles of occiput in three rows, on each side in $\hat{\circ} 2$ (rarely 3 ), 3 (rarely 2 ), 6 (rarely 5), in 우 2 or 3,1 (rarely 2), 6. Prothoracic comb longer than, or in ㅇ at least as

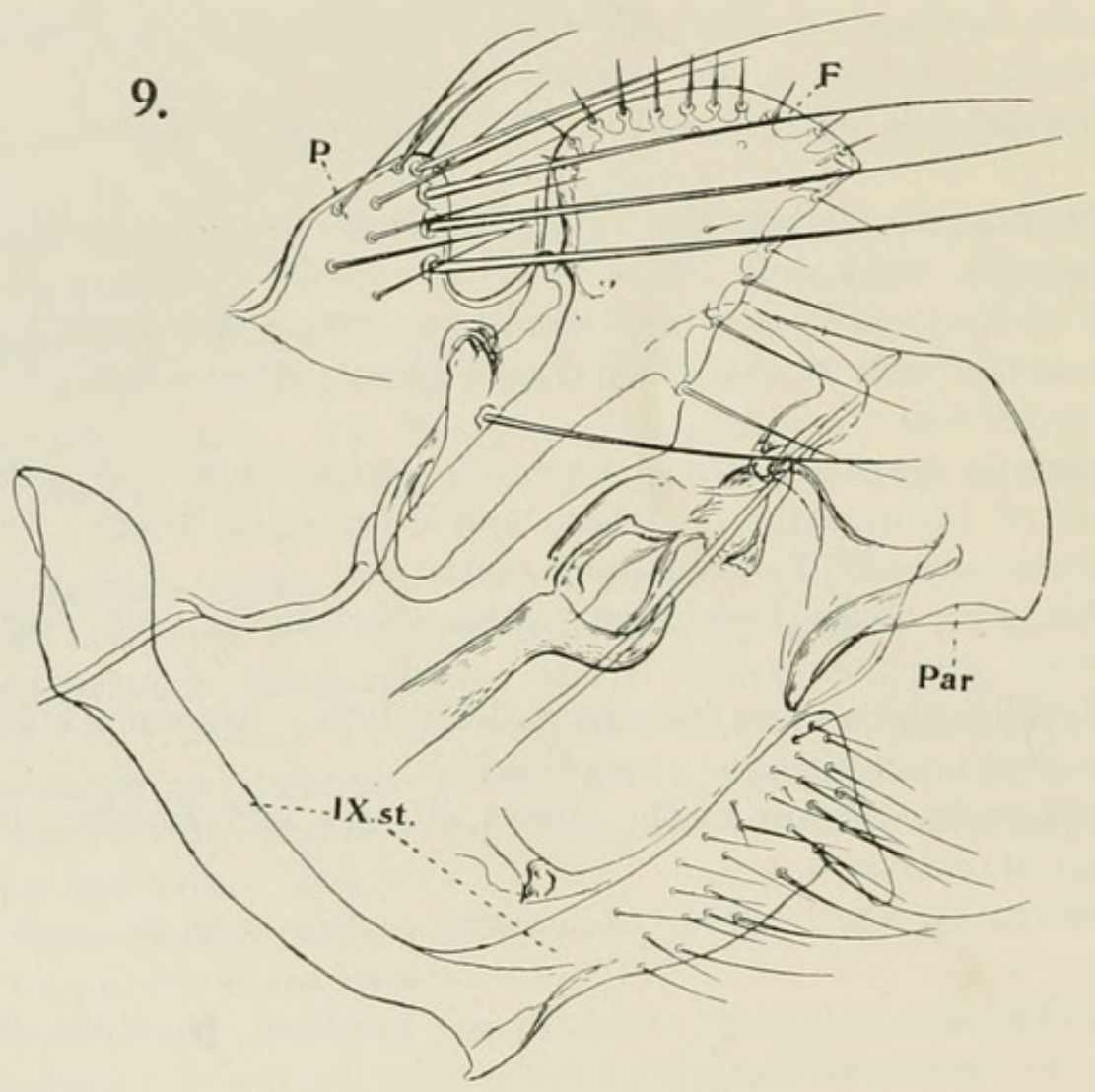

long as, pronotum. On mesopleura 9 or 10 bristles, on metepisternum 4 , on metepimerum 8 to 14. Meso- and metanotum, and abdominal tergites with two rows of bristles, with hardly any additional dorsal bristles, on tergite II 18 to 22,21 to 23 ; usually 4 , rarely 5 below stigma of II, on III 2 or 3 , on VII in of usually 2 , in $q 1$; bristles on VII. $t$. in $\delta 8$ or 9,13 to 17 , in $ᄋ 14$ to 16 , 10 to 15 . Basal abdominal sternite with some lateral bristles posteriorly, besides the ventral ones; in $\delta$ on III to VII 0 to 6,9 to 11 , in 98 to 10,17 or 18. Hindtarsal segment II in $\hat{0}+$ with 2 bristles extending beyond apex of III.

Modified Segments.- $\widehat{0}$. Sternite VIII with 19 to 24 bristles on the two sides together. Apex of clasper divided into an upper and a lower process, the former bearing 4 (rarely 3 ) long submarginal bristles and a variable number of 
lateral and apical ones, apex of lower process rounded, at ventral margin a long bristle. Exopodite $\mathrm{F}$ twice as long as apically broad, apical margin strongly rounded, particularly anteriorly, bearing 10 or 11 pale and rather long spiniform bristles, posterior apical angle a little smaller than $90^{\circ}$, forming a more strongly chitinized nose; posterior margin convex in middle, between this point and apex three long bristles and above these two short thin ones. Ventral arm of IX. st. characteristic : not quite so long as vertical arm, dorsal margin slightly incurved, apex truncate, upper angle smaller than $90^{\circ}$, but rounded off, lower angle prolonged downward into a nose, which is about twice as long as broad and rounded at apex; on side of IX. st. nearly 30 bristles, all pale and thin,

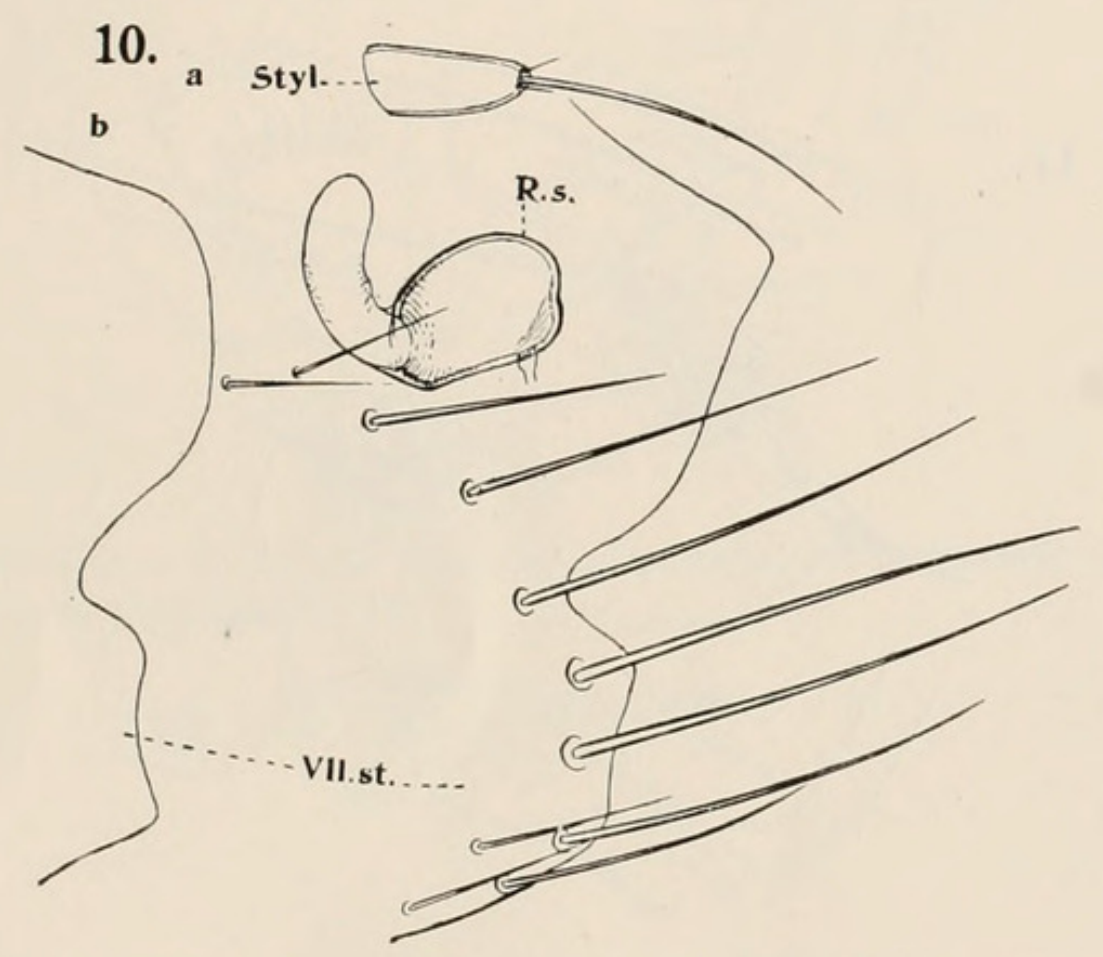

but several of the subventral ones about twice as long as the sclerite is broad in middle. Paramere of penis (Par) apically rounded, its ventral angle about $90^{\circ}$ or a little less.— - . VII. st. considerably variable (cf. text-fig. 5a and 5b taken from two specimens), bearing on the two sides together a posterior row of from 14 to 18 bristles and in front of the row 7 to 12 ; apex sinuate below middle, the upper lobe more or less pointed and ventrally rounded, as in text-fig. $10 \mathrm{a}$, or more rarely broad and rounded as in text-fig. $10 \mathrm{~b}$, the sinus rather narrow, the margin below it excurved and then slightly incurved. Above stigma of VIII. t. 3 to 5 bristles on each side, on lower area 12 to 15 , of which the most distal one is short and stout and subventral like the preceding long bristles ; on inside 8 or 9 , small, some minute; apex of VIII. t. more or less evenly rounded. Stylet two and a half times as long as proximally broad. Bursa copulatrix plus its duct nearly as long as hindtarsal segment II. Spermatheca (R.s.) with head and tail about equal in length, head strongly convex above, somewhat variable.

Length (specimens somewhat extended) : ô $3.0 \mathrm{~mm}$.; Hindfemur: $0.44 \mathrm{~mm}$. ; 90.48 to $0.51 \mathrm{~mm}$.

Hab. Rumania: Cluj (Klausenburg), 27.v.1928, off Spalax typhlus 
transsilvanicus, a series collected by Dr. R. Jeannel, to whom the species is dedicated.

2. Ctenophthalmus ruris sp. nov. (text-figs. 11 ô).

o. Similar to the specimens from the Deliblat and Croatia identified (perhaps erroneously) in the N. C. R. collection as Ct. caucasica Tasch., but proboscis reaching to apex of forecoxa and genital armature different. The only specimen we have is aberrant in having 2 instead of 3 genal spines on each side. Pronotal comb shorter than pronotum.

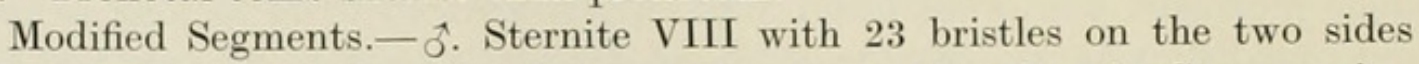
together. Lower apical angle of clasper less projecting than in Ct. caucasica,

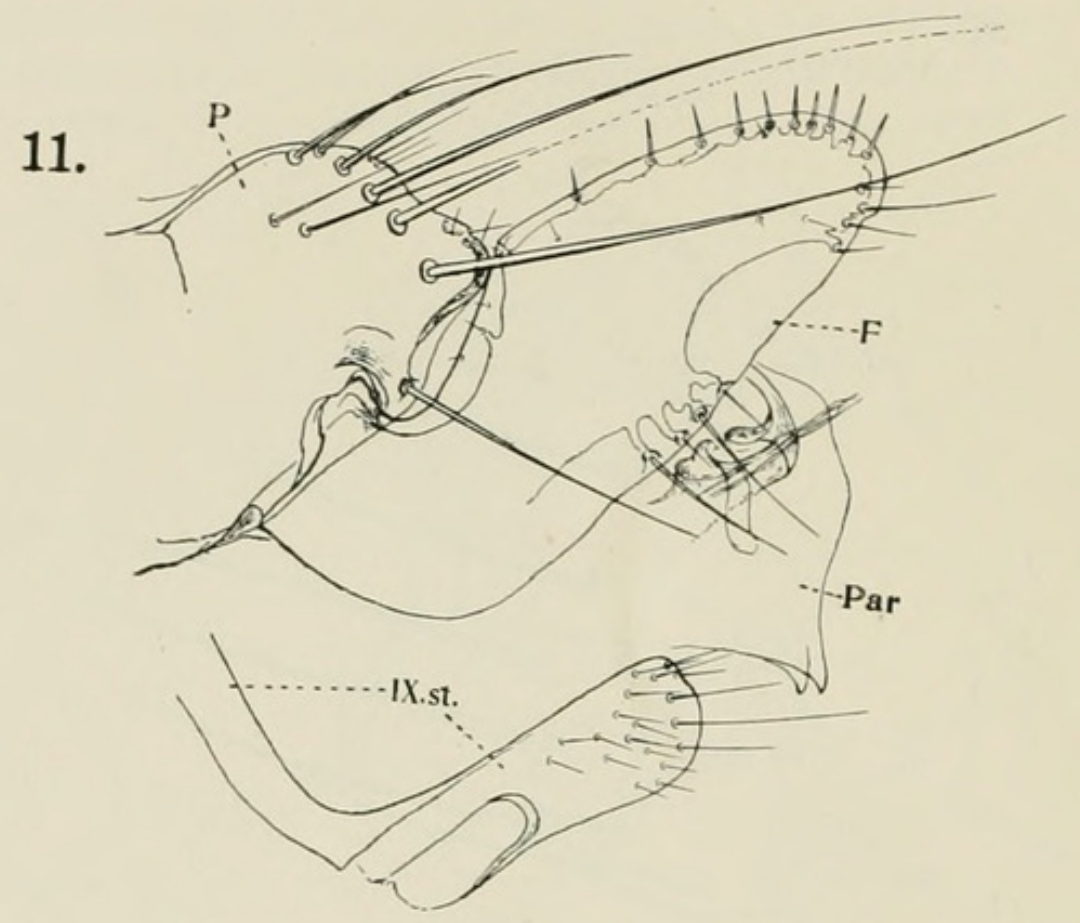

the apical margin above it being but very slightly incurved. Exopodite F shorter and broader, its apex much blunter. Apex of ventral arm of IX. st. slightly wider than middle, subtruneate, strongly rounded ventrally, apical margin faintly incurved below upper angle; about 20 thin bristles, 3 of the distal ones the longest, the middle one of the 3 being about half the length of the ventral arm of the sternite. Ventral angle of paramere (Par) produced downward into a sharp hook.

Hab. Rumania : Dobrogea, May 1913, off Spalax typhlus dolbrogeae, one oิ (M. Aigner).

3. Ctenophthalmus phrator sp. nov. (text-figs. 12 ô, 13 †).

ơ. Similar to the preceding species. Proboscis not quite reaching to apex of forecoxa. Comb longer than pronotum, containing 16 to 19 spines. On meso- and metanotum two rows of bristles, on mesonotum additional dorsal bristles (and, of course, basal ones). Mesopleura with 6 or 7 bristles; metepisternum with 3 , rarely 2 ; metepimerum with 5 or 6 . Abdominal tergites with two rows, I with additional dorsal bristles; bristles in $\hat{\sigma}$ on II 7 to 10 , 14 or 15 , VII 5 to 9,10 to 13 , and in o on II 10 to 14,14 to $16 ; 2$ bristles below stigma on II, one in front of the other, 1 or 2 on VII. Abdominal sternite II 
with 2 ventral bristles, no lateral ones, in $\delta$ on III to VII a row of 5 to 7 , usually 6 , with 0 to 3 bristles in front, usually 0 or 1 , and in $q$ on III to $\mathrm{V} 3$ to 5,8

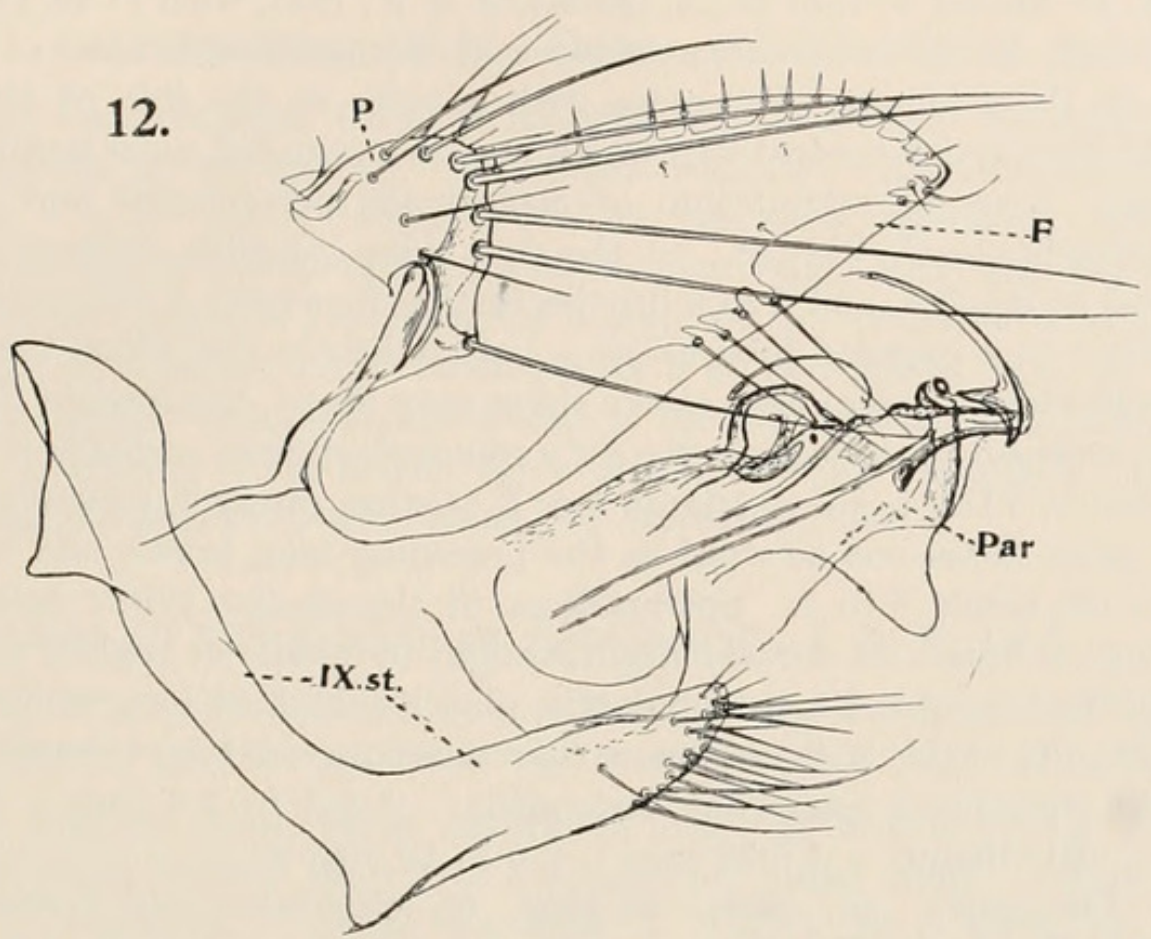

to 11 , on VI 6 to 8,10 to 12 . Longest apical bristle of hindtarsal segment II reaches to or beyond apex of IV.

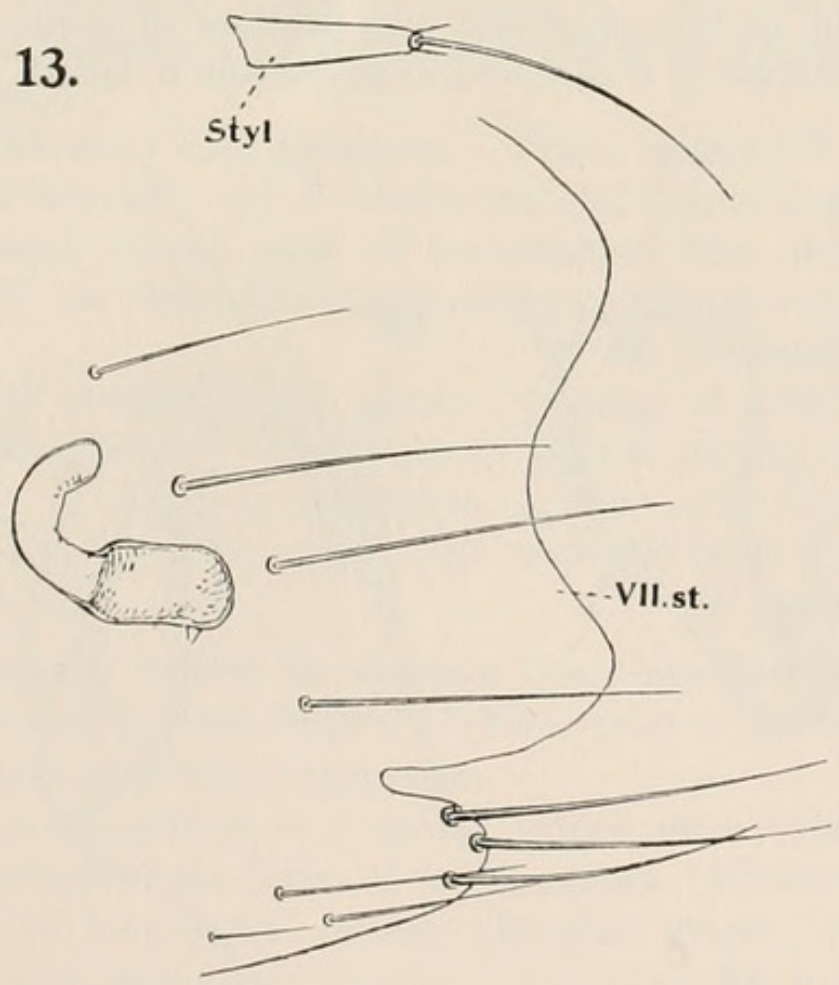

Modified Segments.- $\hat{0}$. On sternite VIII 12 to 17 bristles, on the two sides together. Process $\mathrm{P}$ of clasper not divided by a sinus, being rounded and bearing a row of 4 or 5 long bristles, besides several shorter ones. At ventral margin, where $\mathrm{P}$ is somewhat dilated, a single long bristle. Exopodite $\mathrm{F}$ about two and a half times as long as broad, of the long $C t$. caucasica type; above 
middle of posterior margin 4 or 5 long thin bristles, posterior apical corner somewhat more strongly chitinized, a curved bristle below this angle. Ventral arm of IX. st. similar to that of Ct. spalacis J. \& R. 1911, with 17 to 19 bristles in apical third, which are about as slender as the anterior bristles of VII. t., but most of them longer. Paramere with a hook at the side of the apical tube of the duct and a ventral flap which is either rounded as in text-fig. 7, or subtruncate. Apex of manubrium of elasper sharply pointed and strongly curved upwards.— + . VII. st., on the two sides together, with a posterior row of 10 to 14 bristles, and 7 to 9 bristles further forward; a subventral sinus narrow, below it a rounded lobe bearing 3 stout bristles, of which the ventral one is the shortest; apical area above sinus very broad, the margin incurved, upper and lower angle projecting, strongly rounded, slightly variable in outline. On each side of VIII. t. above stigma 2 or 3 bristles, rarely 4 , on lower area 13 , to 16 , the most distal one as stout as the preceding long bristle and over half its length; on inside 5 to 7 . Spermatheca of the slender type; head nearly twice as long as broad, its dorsal margin straight in middle or slightly incurved ; tail longer than head. Bursa copulatrix plus its duct as long as hindtarsal segment III. Stylet (Styl) slender, more than three times as long as basally broad.

Length (specimens somewhat distended) : ô $2 \cdot 3$ to $2.6 \mathrm{~mm}$.; $q 2.9$ to $3.3 \mathrm{~mm}$.— Hindfemur : ô $0.36 \mathrm{~mm}$.; 0.37 to $0.43 \mathrm{~mm}$.

Hab. Caucasus: no special locality, on Cricetulus and Prometheomys, August 1925 (Montague Clark) ; a series.

4. Amphipsylla primaris botis subsp. nov. (text-fig. $14 \hat{\jmath}$ ).

o. Proportions of the exopodite and position of some of its spiniforms different : apical margin of $\mathrm{F}$ narrower in proportion to length of $\mathrm{F}$; submedian

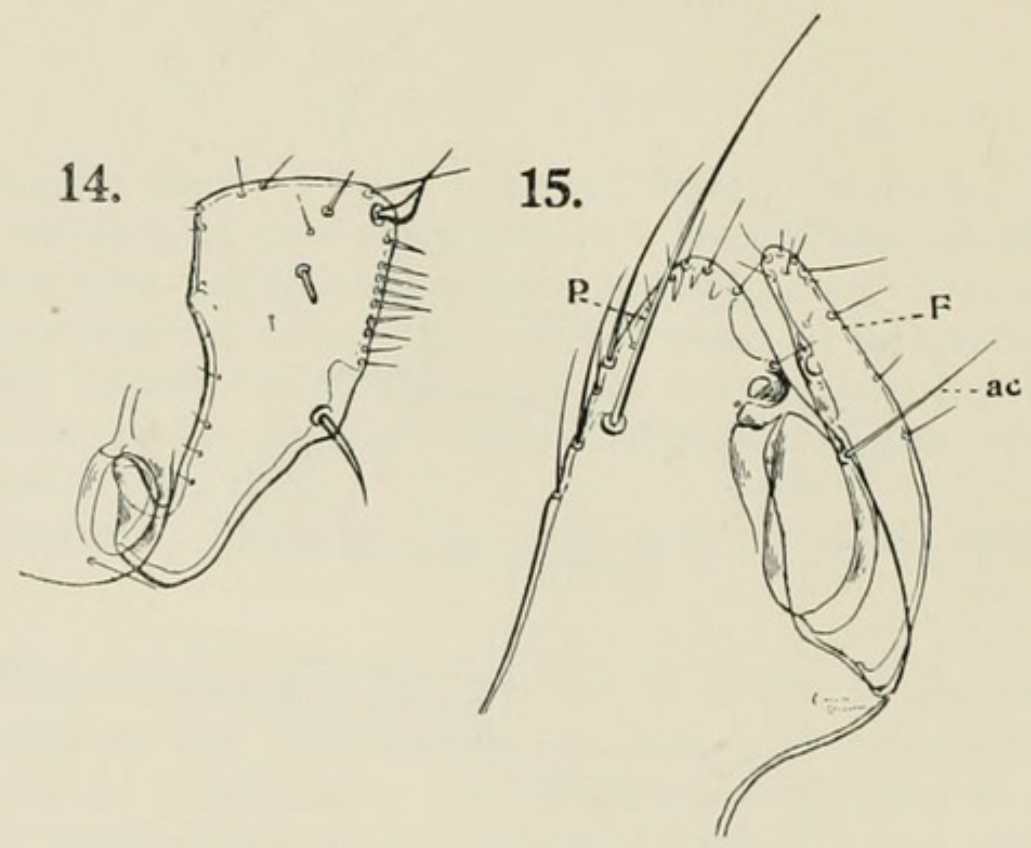

spiniform of hindmargin lower down, placed just above middle; between it and apical spiniform a marginal row of 8 or 9 bristles more or less subspiniform, but pale; lateral spiniform farther away from apical curved spiniform ; inward from apical spiniform and obliquely above lateral one two bristles, of which the upper is subspiniform. 
Hab. Transbaicalia: Tchita, off Microtus sp., September 1923 (Dr. Jettmar) ; one $\hat{\sigma}$.

5. Rhadinopsylla bureschi sp. nov. (text-fig. $150 \hat{)}$ ).

§ิ. Near Rh. casta Jord. 1928 and Rh. integella J. \& R. 1921, all three possibly being subspecies of one species. Abdominal sternites with more bristles: on III 5, IV 5, V 6, VI 6, VII 6, VIII 9 (on the two sides together). Acetabular bristle (ac) far up the posterior margin of clasper, being placed midway between the most ventral point of the posterior margin of the exopodite and the apex of P. Notch of anterior margin of exopodite F at two-thirds. IX. st. distally rather more strongly rounded-dilated than in the allied forms mentioned.

Hab. Bulgaria: Cam-Kuria, Ryla Mts., south of Samokow, $1200 \mathrm{~m}$., 30 July 1924, off Microtus subterraneus (Dr. Buresch) ; one $\hat{o}$.

\section{Key to the Species of Rhadinopsylla J. \& R. 1912.}

The regular, vertical, very dense striation of the lower part of the metepimerum observed in a few genera is very conspicuous in Rhadinopsylla.

A. Frontal tubercle much below middle of frons, its distance from maxillary palpus much shorter than first (= anterior) genal spine. Labial palpus with 5 segments. Tarsal segment $\mathrm{V}$ with 4 or 5 pairs of plantar bristles.

a. Hindtarsal segment II with long bristle in subapical notch reaching in $q$ beyond III, in ô near to apex of V. Rh. bivirgis Roths. 1913.

b. Hindtarsal segment II without long subapical bristle (but with long apical one).

$a^{1}$. Pronotal comb with 14 spines. Tarsal segment $V$ with 4 pairs of lateral bristles. $\hat{\jmath}$ : $\mathrm{F}$ evenly rounded; nose of posterior margin of clasper (upper angle of acetabulum) well above middle.ㅇ: VII. st. with additional bristles in front of row.

Rh. masculana J. \& R. 1912.

$b^{1}$. Pronotal comb with 18 spines (inclusive of small ventral ones). Tarsal segment $\mathrm{V}$ with 5 pairs of plantar bristles, at least in some tarsi. $\hat{o}$ : F nearly straight in middle ; nose of posterior margin of clasper in middle._— III to VII

Rh. cedestis Roths. 1913.

B. Frontal tubercle near middle, its distance from maxillary palpus about as long as (or even longer than) ventral (= first) spine of genal comb.

c. Labial palpus with 6 to 8 segments.

$c^{1}$. Genal comb with 6 or 7 spines, upper spine equalling the next.

Prothoracic comb with 24 or 25 spines. Hindtarsal segment II with one long apical bristle. In $q$ no bristles above stigma of VIII. t. or only one . . . . . Rh. insolita, cf. p. 158. $d^{1}$. Genal comb with 4 spines, upper spine shorter than third.

d. Labial palpus with 5 segments.

Rh. jaonis Jord. 1929.

$e^{1}$. Genal comb with 4 spines; metepisternum fused with metanotum.

Rh. sectilis J. \& R. 1923. 
$f^{1}$. Genal comb with 7 or 8 spines. Pronotal comb with 28. Hindtarsal segment II with one long apical bristle, which, in 9 , does not reach beyond IV. On VIII. t. some bristles above stigma.

Rh. dives, ef. p. 157.

$g^{1}$. Genal comb with 5 (rarely 4 or 6 ) spines.

$a^{2}$. Hindtarsal segment II with one long apical bristle reaching beyond IV. ô: IX. st. broadened. $q$ : tail of spermatheca not caved in . . . . Rh. dahurica J. \& R. 1923.

$b^{2}$. Longest apical bristle of hindtarsal segment II reaching beyond apex of IV.- $\hat{\sigma}$ : IX. st. very narrow.- + : tail of spermatheca caved in on posterior side . . . . Rh. tenella cf. p. 158.

$c^{2}$. Longest apical bristle of hindtarsal segment II not reaching beyond apex of IV.

$a^{3}$. Upper genal spine much shorter and much broader than first spine. Pronotal comb with 14 spines. Spermatheca large, tail not caved in . . $\quad R h$. pentacanthus Roths. 1897.

$b^{3}$. Upper genal spine not, or not much, shorter than first. Pronotal comb with 20 spines or more.

$a^{4}$. Upper and lower genal spines practically alike. $\hat{\sigma}$ : bristles of VIII. st. apical . . Rh. isacanthus Roths. 1907.

$b^{4}$. Upper genal pine broader than first and somewhat shorter.

$a^{5}$. 0 : notch of anterior margin of exopodite $\mathrm{F}$ much below middle; IX. st. gradually narrowed; acetabular bristle on a level with lowest point of F._ theca caved in ; genal comb usually with 6 spines

Rh. mesa J. \& R. 1920.

$b^{5}$. $\hat{o}$ : notch of anterior margin of $\mathrm{F}$ just below middle; IX. st. dilated-rounded at apex; acetabular bristle on a level with lowest point of F._-

Rh. integella J. \& R. 1921.

$c^{5}$. $\hat{\sigma}$ : like $b^{5}$, acetabular bristle a little above lowest point of F.—o: tail of spermatheca somewhat swollen, not caved in . . . . Rh. casta Jord. 1928.

$d^{5}$. $\hat{\sigma}$ : notch of anterior margin of $\mathrm{F}$ much above middle; acetabular bristle at two-thirds of posterior margin of clasper; IX. st. rounded-dilated apically; VIII. st. with a row of 4 or 5 bristles on each side. $+q$ : not known . . . . R R. bureschi, ef. p. 183.

$e^{5}$. $\hat{\sigma}$ : notch of anterior margin of $\mathrm{F}$ much above middle; acetabular bristle more or less on a level with lowest point of F; VIII. st. on each side with a row of 6 or 7 bristles.—o : tail of spermatheca not caved in.

Rh. fraternus Baker 1895.

6. Ischnopsyllus teres sp. nov. (text-figs. $16 \hat{\jmath}, 17$ and 18 우).

ऽ우. In size similar to $I$. intermedius Roths. 1898, but abdominal combs with fewer spines and modified segments very different, particularly in $\widehat{\delta}$.

Head.-Supra-oral incrassation (text-fig. 17) widest at apex, which is more or less curved downward, sometimes rather more so than in our figure; the 
sexes differ in there being in the $q$ a strongly chitinized dark area behind the incrassation, while in the $\hat{o}$ the posterior boundary of this dark area is contiguous with the apical margin of the incrassation. Spines in metanotal and abdominal combs : in of on met. 22 to 27 , I 7 to 9 , II 18 , III 17 to 22 , IV 12 to $15, \mathrm{~V} 9$ to 12 , VI 8 to 10 ; in $q$ on met. 24 to 26 , I 7 to 9 , II 16 to 20 , III 13 to 18, IV 10 to 13 , V 8 (rarely 9), VI 6 to 11 (usually 7 or 8 ). One complete row on abdominal tergites, containing on II to VII 12 to 14 bristles, in front of the row 2 to 6 , in $q$ sometimes 7 , small bristles. On the sternites (on the two sides

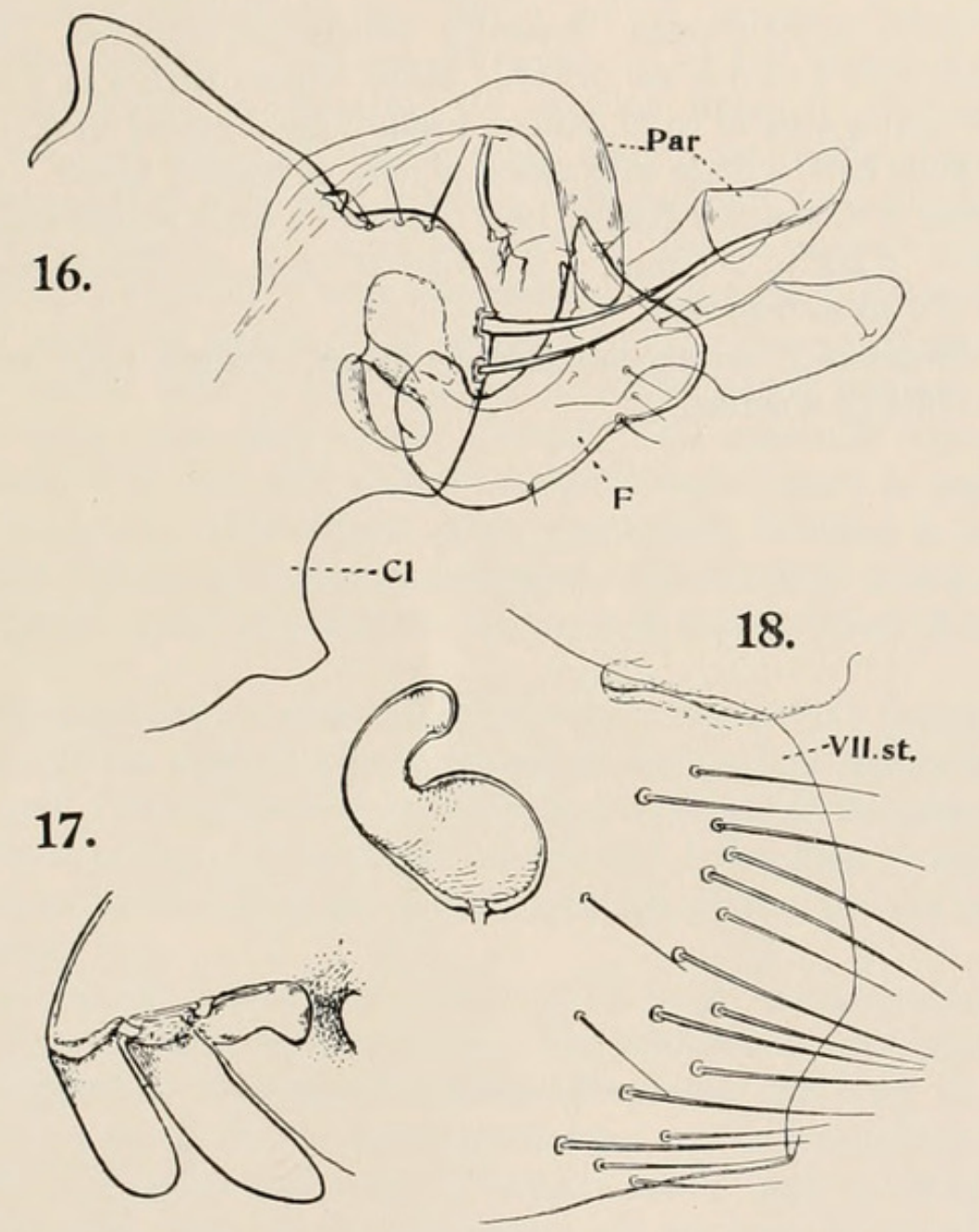

together) in $\delta$ on III 2 or 3 , IV and V 4, VII 9 ; in $q$ on III 6 to 8 , IV and V 7 to 11 .

Proportional average lengths of tarsal segments: midtarsus in $\hat{0} 33,21$, $14,9,15$; in $q 32,19,14,9,15$; hindtarsus in $048,25,17,17$; in $q 43,24$, $16,10,17$.

Modified Segments._- on tergite VIII 12 to 17 bristles. VIII. st. club-shaped, upper apical corner drawn out into a small hook curved frontad; on side of dilated apex 5 long bristles, slightly widened-flattened in basal half, ventrally 2 long bristles, strongly widened in basal half, from these bristles frontad a row of about 6 small ones. Clasper (Cl) with a dorsal, subtriangular, rounded-off projection, oblique apical margin from this hump to one-half straight, the lower half excurved, bearing ventrally 2 large acetabular bristles, of which the upper is the thicker, at upper portion of this curved margin 3 small bristles ; 
ventral margin of clasper from base of exopodite rounded-excised, this sinus bounded frontally by a projection. Exopodite about twice as long as broad, anterior margin almost evenly incurved from above base to apex, which is sharply pointed; disto-apical margin nearly straight, very slightly incurved, ventral margin rounded proximally, incurved beyond middle, rounded distally, merging into apical margin in an even curve ; bristles all small, somewhat variable in number. Apical armature of penis characteristic: dorsally a ribbon-like sclerite which gradually curves downwards, and below it a slipper-like sclerite projecting distad._- + Sternite VII with 30 to 35 bristles on the two sides together; apex subtruncates ventrally somewhat incurved. Tergite VIII above stigma with 1 to 2 or no bristles, below stigma with 4 or 5 long ones, on widened triangular area 19 to 22 , and on inside 3 stout apical ones. Stylet short, slender in apical half, a little over twice as long as basally broad. Spermatheca similar to that of $I$. simplex Roths. 1906, its head a little longer than broad.

Length: $\hat{o} 2.3$ to $2.7 \mathrm{~mm}$.; $q 2.5$ to $2.7 \mathrm{~mm}$.— Hindfemur $\hat{o} 0.39$ to $0.45 \mathrm{~mm}$.; ; 0.40 to $0.44 \mathrm{~mm}$.

Hab. Caucasus: no special locality given, August 1925, off Myotis sp. (Montague Clark) ; a series. 


\section{$2 \mathrm{BHL}$ Biodiversity Heritage Library}

1929. "Some new Palaearctic fleas." Novitates zoologicae : a journal of zoology in connection with the Tring Museum 35, 178-186.

https://doi.org/10.5962/bhl.part.10825.

View This Item Online: https://www.biodiversitylibrary.org/item/22617

DOI: https://doi.org/10.5962/bhl.part.10825

Permalink: https://www.biodiversitylibrary.org/partpdf/10825

\section{Holding Institution}

Natural History Museum Library, London

\section{Sponsored by}

Natural History Museum Library, London

\section{Copyright \& Reuse}

Copyright Status: In copyright. Digitized with the permission of the rights holder.

Rights Holder: The Trustees of the Natural History Museum, London

License: http://creativecommons.org/licenses/by-nc-sa/4.0/

Rights: http://biodiversitylibrary.org/permissions

This document was created from content at the Biodiversity Heritage Library, the world's largest open access digital library for biodiversity literature and archives. Visit BHL at https://www.biodiversitylibrary.org. 